\title{
IS METABOLOMICS THE DIAGNOSTIC TOOL FOR MEDICAL DIAGNOSTICS OF CANCER? AN EXAMPLE BASED ON LUNG AND BREAST CANCER
}

\author{
A. Lamasz'1, W. Barg², P. Mlynarz' \\ ${ }^{1}$ BIOORGANIC CHEMISTRY GROUP, FACULTY OF CHEMISTRY, WROC $Ł A W$ UNIVERSITY \\ OF SCIENCE AND TECHNOLOGY, WROC $Ł A W$, POLAND \\ 2DEPARTMENT OF PHYSIOLOGY, WROCLAW MEDICAL UNIVERSITY, WROCLAW, POLAND
}

Background. Metabolomics is a relatively new diagnostic tool that allows a deep insight into the body metabolism at a cellular level.

Objective. This paper provides a comprehensive view into the metabolomics methodology and shows usefulness of this approach in diagnosing and stratifying lung and breast cancers.

Methods. Literature review of metabolomics studies and its clinical application in the diagnosis of cancerselected studies.

Results. In general, the metabolomic approach comprises three steps: 1) sampling and preparing biofluids or tissue homogenates, 2) identification of low-molecular weight compounds up to $1.0 \mathrm{kDa}$ using nuclear magnetic resonance, mostly ${ }^{1} \mathrm{H}-\mathrm{NMR}$ and/or mass spectrometry, and finally 3) data processing and analysing. It is possible to identify a set of metabolites, which is specific for a certain metabolic status (the metabolic fingerprint). Furthermore, this set of metabolites provides information of possible pathomechanisms involved in the disease process i.e. information about the disease etiology. It has been proven that the change in metabolome precedes; not only clinical symptoms but other laboratory findings as well. Consequently, this approach, if sufficiently validated, seems to be very promising especially in screening and early diagnosing.

Conclusions. It was demonstrated that metabolomic approach allows to discriminate patients with cancer from healthy persons, as well as to differentiate between clinical stages of the cancer.

KEY WORDS: metabolomics; metabolome; breast cancer; lung cancer.

\section{Introduction}

To understand the complex processes occurring in the living systems the holistic approach should be used within employing all established multilevel approaches, currently is called 'omics science'. In general, there are more than 100 types of omics subjects, including sciences such as: genomics, transcriptomic, proteomics, and metabolomics. This approach includes all-important live processes from information storage transcription processes, protein production, up to enzymes actions transforming certain substrates to products maintaining the cell living processes. While genomics and proteomics have been successfully introduced to routine diagnostics, metabolomics is still on the runway despite its assessed potential [1].

Corresponding author: Piotr Młynarz, Ph.D., D.SC., Bioorganic Chemistry Group, Faculty of Chemistry, Wrocław University of Science and Technology, Wroclaw, Poland

E-mail: piotr.mlynarz@pwr.edu.pl

Phone number: +48713203616
Metabolomics refers to the analysis and interpretation of ongoing processes in living organisms at the end of life chain consisting of genomics-transcriptomics-proteomics-metabolomics science. Metabolomics might be strongly influenced by external factors such as environment, life style, diet, medications, as well as by additional metabolite input from the body's microbiomes. Metabolites are delineated as lowmolecular weight compounds (LMWC) up to $1.0 \mathrm{kDa}$. Those compounds are carbohydrates, fatty acids, lipids, amino acids, nucleosides, or other organic molecules which are involved in biochemical reactions as substrates, intermediates, and/or final products. The set of body's metabolites ultimately form its characteristic metabolome. Metabolome is a dynamic system, which is largely dependent on internal biochemical reaction and external factors mentioned above $[1,2]$. Metabolomics is a comparative science, e.g. the obtained information should be compared to the referenced one or vice versa. With this approach metabolomics can be 
regarded as a diagnostic tool, which in principle enables to describe current metabolic status of cells, tissues, and organs. Simply put, it can define the general health of a living organism. This is done by analysing body fluids, either secreted like urine, saliva, mother milk, stool, or obtained during standard medical sampling procedures such as serum, plasma, cerebrospinal fluid, tissue samples etc.. The samples collection for metabolomics studies is relatively simple, however certain procedures must be followed [3]. The patients must follow standard requirements: they should be fasting and reports all designated therapy, addictions, and medical history. The samples taken should be stored at $-80^{\circ} \mathrm{C}$ or preserved in liquid nitrogen $[2,4]$. This low storage temperature ensures the maintaining of metabolic composition, i.e. minimalizing possible changes in the metabolic profile after sampling, and protects against potential influence of the donor's microbiome $[5,6]$.

Comprehensive or even partial determination of the metabolome is not possible with a single analytical method due to different levels of detection limits and different group determination. There are many analytical methods employed for metabolomics, each of them having both advantages and disadvantages. However, there are two main methods, which are routinely used in metabolomics studies: NMR (Nuclear Magnetic Resonance, mostly ${ }^{1} \mathrm{H}-\mathrm{NMR}$ ) and MS (Mass Spectrometry) hyphenated with separations techniques [2]. Studies based on both NMR and MS have a common pathway:

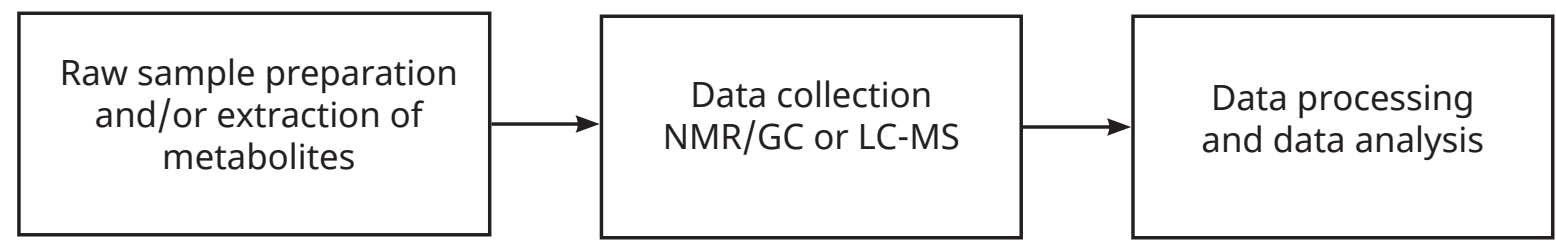

Fig. 1. Typical workflow for metabolomics studies [2].

One of the most important advantages of the MS method is the sensitivity to femtomole concentration, which allows analysing up to several thousand molecules in a certain sample, resulting in precise molecular description in the tested specimen. On the other hand, reproducibility with MS is usually worse as compared to NMR spectroscopy. Unlike the MS, the NMR method provides high reproducibility with the ability to combine structure analysis and detection of the range of 30-90 molecules without sample destruction (biofluids). However, the detection limit of individual compounds is shifted several rows and strongly depend on the time of measurements (acquisition). The advantage of this method is the ability to measure different compounds such as amino acids, nucleosides, amines, acids, etc. all at the same time. The data obtained with both methods are both quantitative and qualitative among the set of detected metabolites [7].

The results obtained are further elaborated using chemometric multidimensional discriminatory methods. For this type of studies, the methods most commonly used are: unsupervised PCA, supervised PLS (Partial Least Squares
Discriminant Analysis), and OPLS-DA (orthogonal version of PLS-DA). These approaches allow describing each subject not with 2 or 3 variables (chemical compounds or characteristic parameters) as in routine statistical analysis, but even hundreds of variables (chemical compounds - metabolites) can be analysed with selection of the most specific ones. Those compounds or more often sets of compounds can be employed as biomarkers for discriminating patients from healthy individuals or for staging of the disease [8].

Application of metabolomics in the diagnosis of cancer - selected studies

\section{Lung cancer}

In Europe, lung cancer accounts for approximately $20 \%$ of all cancer deaths, with 376000 deaths in 2008. Unfortunately, the early stages of this cancer are usually lowsymptomatic and final diagnosis is made late in the natural history of the disease. Consequently, effective treatment is not possible up to $90 \%$ of cases, and the overall 5-year survival rate is $11.2 \%$ for men and $13.9 \%$ for women [9]. The metabolomic studies of lung cancer are based on various body fluids, predominantly blood serum, urine, and saliva. The most 
common type of lung cancer is non-small cell lung cancer (NSCLC). The main recognized risk factor for NSCLC is cigarette smoking. Additionally, COPD is considered an independent risk factor of lung cancer [10]. Our team has demonstrated a possibility to differentiate between patients with COPD and with two stages of NSCLC: an early NSCLC (E-NSCLC) and an advanced NSCLC (A-NSCLC). Using ${ }^{1} \mathrm{H}$ NMR method we were able to identify 45 metabolites in patients' serum. Concentrations of acetate, citrate, and methanol were significantly reduced in lung cancer subjects. In contrast, concentrations of $\mathrm{N}$-acetylated glycoproteins, leucine, lysine, mannose, choline, lipids (L3 + L4), and two other unknown compounds were increased in for patients suffering cancer in all three performed comparisons: NSCLC vs. COPD, E NSCLC vs. COPD and ANSCLC vs. COPD [10]. Similar results were obtained by Musharraf et al [11]. Using GC-MS method for tracing metabolites in plasma, they were able to discriminate lung cancer patients from COPD patients, as well as healthy non-smokers and healthy smokers with high sensitivity $(96.2 \%)$ and specificity (92.05\%).

Another research group focused on differentiating early lung cancer patients from healthy controls. They used ${ }^{1} \mathrm{HMR}$ and rapid resolution liquid chromatography (RRLC) methods to investigate metabolites in serum and identified 25 metabolites, which were up or down regulated. Those findings proved disorders in glycolysis, lipid metabolism, choline phospholipid metabolism, one-carbon metabolism, and amino acid metabolism. The use of both methods enabled diagnosing early stage of lung cancer with a very high accuracy [12]. Mass spectrometry hyphenated with gas chromatography (GC-MS) was used by Horia and co-workers [13]. They demonstrated that the levels of 23 of 58 serum metabolites and 48 of 71 sampled from tissue were significantly changed in patients with lung cancer with I-IV stage as compared, with healthy volunteers. An early cancer stage was also investigated by other group using LC-MS method. In this study, the achieved AUC value based on 12 metabolites was 0.836 [14].

Urine also has a strong discriminative potential in lung cancer diagnosing. This was proven in a study performed using ${ }^{1} \mathrm{H}$ NMR method by Carrola and colleagues [15]. The main metabolites differentiating between healthy controls and lung cancer patients were: hippurate, trigonelline, $\beta$-hydroxyisovalerate, a-hydroxyisobutyrate, $\mathrm{N}$-acetylglutamine, and creatinine. They were able to develop a classification model, which confirmed $93 \%$ sensitivity and $94 \%$ specificity with overall classification rate of $93.5 \%$. [15]. The studies performed by LC-MS method on urine samples from cohort of 469 patients with lung cancer and 536 controls revealed two biomarkers: creatine riboside and $\mathrm{N}$-acetylneuraminic acid, which were significantly increased in non-small cell lung cancer and were associated with worse prognosis [16].

Exhaled breath condensate (EBC) seems to be naturally associated with lung cancer. Indeed, studies on EBC performed with GC-MS [17] and LC-MS [18] proved diagnostic usefulness of EBC differentiating lung cancer patients, COPD patients, smokers, ex-smokers, and healthy controls. In addition to the above mentioned biofluids, also sweat should be included, which was successfully used to differentiate the lung cancer patients from control individuals with risk factors and without them by its analysis by LC-MS system [19].

Recently, a very promising study has been published by Shen et al.. Using two-stage study design and advanced metabolon platform they were able to identify four metabolites, which may be useful biomarker candidates for identifying patients, who may benefit from platinum-based chemotherapy in advanced NSCLC [20]. The comprehensive review on lung cancer biomarkers and metabolomics methods has been published recently [21].

\section{Breast cancer}

Breast cancer (BC) is the most common cancer in women worldwide and the morbidity keeps rising. Incidence vary from 19.3 per 100,000 women in Eastern Africa to 89.7 per 100,000 in Western Europe [22, 23]. Some decrease in the number of death caused by BC is observed mainly due to the improvement in early diagnostics [24]. Nevertheless, routine methods currently used to detect BC usually are not effective, especially in the very early stages [25].

A new approach in cancer diagnostics involves the use of metabolomics tools for blood serum and urine analysis $[25,26,27]$. Metabolomic-based diagnosing not only seems to allow discriminating healthy controls from BC subjects, but also differentiating metastatic $B C$ from early stages of $B C$ as well $[28,29]$.

Previous studies proved that $B C$ can be diagnosed by NMR spectroscopy and by MS, both by use of serum and urine [27, 30, 31]. 
However, those metabolomic studies involved relatively small groups and, utilized various protocols and methods [32]. Therefore, a more integrated and coherent methodology should be used [33].

The GC-MS method can be used for metabolic profiling of serum. Using this method, it was possible to differentiate patients with BC from patients with non-malignant tumours, and from healthy controls. Sets of amino acids, fatty acids, and lysolipids allowed differentiating these three groups [31]. There is also evidence that polar compounds analysis has been successfully applied for metabolomicbased BC diagnosing in tissue samples. Chae and co-workers used HR-MAS ${ }^{1} \mathrm{H}$ NMR method for retrospective analysis in the patients with ductal carcinoma in situ (DCIS) diagnosed on preoperative biopsy. The univariate analysis proved that choline-containing compounds did not differ between the groups, while GPC/PC ratio, myo-inositol, and succinate were higher in the 'pure' DCIS group as compared to the invasive carcinoma subjects. Multivariate analysis OPLS-DA could discriminate to some degree between these two groups [34]. Comparable results were obtained in other groups. In a study based on add space ${ }^{1} \mathrm{H}$ NMR method the authors were able to distinguish between the non-invasive intraductal carcinoma and invasive ductal carcinoma patients. Histidine concentration was significantly lower in the patients with invasive ductal carcinoma. In contrast, those patients presented higher concentrations of glucose, lactate, tyrosine, and lipids in plasma samples, as compared to the non-invasive carcinoma group [35].

It is also possible to differentiate metastatic BC patients from the ones with a localized, early-stage disease. Serum analysis with NMR spectroscopy identified 9 metabolites: histidine, acetoacetate, glycerol, pyruvate, glycoproteins (N-acetyl), mannose, glutamate, and phenylalanine concentrations, all of which were significantly different, than those in the other studied groups [26].

Volatile organic compounds (VOC) from urine samples can also be used for BC diagnosis.
In the study of Silva et al., gas chromatographymass spectrometry was used to obtain metabolomic patterns of 26 BC patients and 21 healthy individuals. Of the 79 volatile identified metabolites six compounds were of diagnostic power: (-)-4-carene, 3-heptanone, 1,2,4-trimethylbenzene, 2-methoxythiophene, phenol, and dimethylsufide. All of them were able to successfully discriminate between the groups [30].

More holistic approach was suggested by Bro et al. In a retrospective study they combined ${ }^{1} \mathrm{H}$ NMR data with other relevant biological and phenotypic information to construct a patient's biocountour. With this approach the authors could predict an increased risk of BC, a few years before its occurrence with sensitivity and specificity well above $80 \%$ [36]. A very interesting paper aiming on possible associations of dietrelated metabolites with $\mathrm{BC}$ risk was published recently by Pleydon et al.. Using CE-MS method they identified a bunch of metabolites, which were moderately correlated with increased risk of estrogen receptor related to $\mathrm{BC}$ development [37]. The annually increasing literature data proves the usefulness of metabolomics in BC $[33,38]$.

\section{Conclusions}

Data from the literature clearly demonstrate the usefulness of metabolomic approach in diagnostics of lung cancer, breast cancer, and many other diseases. Despite this, the metabolomic approach is still not routinely implemented into medical protocols. This results from many factors. Analytical methods used for metabolomic research are neither standardized nor validated. Consequently, it is difficult to: compare results obtained by various research groups, and determine the definitive clinical recommendations. Threfore we need more and more research to overcome these difficulties. However, in the future the metabolomic approach with fingerprinting and profilingbased methods, combined together with predictive-discrimination statistical models should be the method of choice for preventive, screening, and treatment research. 


\title{
МЕТАБОЛОМІКА - НОВИЙ ПІДХІД ДО ДІАГНОСТУВАННЯ РАКУ? НА ПРИКЛАДІ РАКУ ЛЕГЕНЬ ТА МОЛОЧНИХ ЗАЛОЗ
}

\author{
A. Lamasz', W. Barg' ${ }^{2}$ P. Mlynarz'1 \\ 1 - BIOORGANIC CHEMISTRY GROUP, FACULTY OF CHEMISTRY, WROC ŁAW UNIVERSITY OF SCIENCE \\ AND TECHNOLOGY, WROC $Ł A W$, POLAND \\ 2 - DEPARTMENT OF PHYSIOLOGY, WROCLAW MEDICAL UNIVERSITY, WROCLAW, POLAND
}

\begin{abstract}
Вступ. Метаболоміка це відносно новий діагностичний підхід, який дозволяє аналізувати метаболічні процеси на рівні клітини.

Мета дослідження та методи - огляд технології аналізу метаболоміки та ії використання у клінічній практиці для діагностики певних злоякісних захворювань.

Результати. Загалом, метаболомічний підхід включає три етапи: 1) відбір проб біоологічних матеріалів, 2) ідентифікація низькомолекулярних сполук масою до 1,0 кДа з використанням ядерного магнітного резонансу таІ або мас-спектрометрії, 3) обробка та аналіз даних.

Сьогодні ми можемо визначити набір метаболітів, що є специфічним для певного метаболічного статусу (так званий «метаболічний відбиток»). Цей набір метаболітів дасть можливість оцінити певні патогенетичні ланки та визначитися з етіологією захворювання. Доведено, що зміни в метаболомі передують, не лише появі периих клінічних ознак та симптомів, але й будь-яким змінам у клініко-лабораторних аналізах. Отже, метаболомічний підхід може бути перспективним для скринінгу та ранньої діагностики.

Висновки. Доведено, що метаболоміка дозволяє первинно діагностувати та провести диференціальний діагноз стадії злоякісного процесу.

КЛЮЧОВІ СЛОВА: метаболоміка; метаболіти; рак молочної залози; рак легень.
\end{abstract}

\section{References}

1. Barding GA, Salditos R, Larive CK. Quantitative NMR for bioanalysis and metabolomics. Analytical and bioanalytical chemistry. 2012 Sep 1;404(4):1165-79.

2. Kettaneh N, Berglund A, Wold S. PCA and PLS with very large data sets. Computational Statistics \& Data Analysis. 2005 Jan 1;48(1):69-85.

3. https://www.erswhitebook.org/chapters/ lung-cancer/

4. Deja S, Porebska I, Kowal A, Zabek A, Barg W, Pawelczyk K, Stanimirova I, Daszykowski M, Korzeniewska A, Jankowska R, Mlynarz P. Metabolomics provide new insights on lung cancer staging and discrimination from chronic obstructive pulmonary disease. Journal of Pharmaceutical and Biomedical Analysis. 2014 Nov 1;100:369-80.

5. Musharraf SG, Mazhar S, Choudhary MI, Rizi N. Plasma metabolite profi and chemometric analyses of lung cancer along with three controls through gas chromatography-mass spectrometry. Scientific Reports. 2015 Feb 25;5:8607.

6. Zhang X, Zhu X, wang C, Zhang H, Cai Z. Nontargeted and targeted metabolomics approaches to diagnosing lung cancer and predicting patient prognosis. Oncotarget. 2016 Sep 27;7(39):63437-48.

7. Hori S, Nishiumi S, Kobayashi K, Shinohara M, Hatakeyama Y, Kotani Y, Hatano N, Maniwa Y, Nishio W, Bamba T, Fukusaki E. A metabolomic approach to lung cancer. Lung Cancer. 2011 Nov 1;74(2):284-92.

8. Klupczynska A, Dereziński P, Garrett TJ, Rubio VY, Dyszkiewicz W, Kasprzyk M, Kokot ZJ. Study of early stage non-small-cell lung cancer using orbitrap-based global serum metabolomics. Journal of Cancer Research and Clinical Oncology. 2017 Apr 1;143(4):649-59.
9. Carrola J, Rocha CM, Barros AS, Gil AM, Goodfellow BJ, Carreira IM, Bernardo J, Gomes A, Sousa V, Carvalho L, duarte IF. Metabolic signatures of lung cancer in biofluids: NMR-based metabonomics of urine. Journal of Proteome Research. 2010 Nov 23;10(1):221-30.

10. Mathé EA, Patterson AD, Haznadar M, Manna SK, Krausz KW, Bowman ED, Shields PG, Idle JR, Smith PB, Anami K, Kazandjian DG. Noninvasive urinary metabolomic profiling identifies diagnostic and prognostic markers in lung cancer. Cancer Research. 2014Apr;74(12):3259-70.

11. Peralbo-Molina $A$, Calderón-Santiago $M$, Priego-Capote $F$, Jurado-Gámez B, de Castro ML. Identification of metabolomics panels for potential lung cancer screening by analysis of exhaled breath condensate. Journal of breath research. 2016 Mar 23;10(2):026002.

12. López-Sánchez LM, Jurado-Gámez B, FeuCollado N, Valverde A, Cañas A, Fernández-Rueda JL, Aranda E, Rodríguez-Ariza A. exhaled breath condensate biomarkers for the early diagnosis of lung cancer using proteomics. American Journal of Physiology-Lung Cellular and Molecular Physiology. 2017 Jun 15;313(4):L664-76.

13. Calderón-Santiago M, Priego-Capote F, Turck N, Robin X, Jurado-Gámez B, Sanchez JC, de Castro MD. Human sweat metabolomics for lung cancer screening. Analytical and Bioanalytical Chemistry. 2015 Jul 1;407(18):5381-92.

14. Shen J, YeY, Chang DW, Huang M, Heymach JV, Roth JA, Wu X, Zhao H. Circulating metabolite profiles to predict overall survival in advanced nonsmall cell lung cancer patients receiving first-line chemotherapy. Lung Cancer. 2017 dec 1;114:70-8. 
15. Yu L, Li K, Zhang X. Next-generation metabolomics in lung cancer diagnosis, treatment and precision medicine: mini review. Oncotarget. 2017 Dec 29;8(70):115774-86.

16. http://www.who.int/cancer/detection/ breastcancer/en/index1.html

17. Zhang AH, Sun H, Qiu S, Wang XJ. Metabolomics in noninvasive breast cancer. Clinica Chimica Acta. 2013 Sep 23;424:3-7.

18. Senkus E, Kyriakides S, Ohno S, Penault-Llorca F, Poortmans P, Rutgers E, Zackrisson S, Cardoso F. Primary breast cancer: ESMO Clinical Practice Guidelines for diagnosis, treatment and follow-up. Annals of Oncology. 2015 Sep 1;26(suppl_5):v8-30.

19. Asiago VM, Alvarado LZ, Shanaiah N, Gowda GN, Owusu-Sarfo K, Ballas RA, Raftery D. Early detection of recurrent breastcancer using metabolite profiling. Cancer Research. 2010 Nov 1;70(21): 8309-18.

20. Jobard E, Pontoizeau C, Blaise BJ, Bachelot T, Elena-Herrmann $B$, Trédan $O$. A serum nuclear magnetic resonance-based metabolomic signature of advanced metastatic human breast cancer. Cancer Letters. 2014 Feb 1;343(1):33-41.

21. Kim Y, Koo I, Jung BH, Chung BC, Lee D. Multivariate classification of urine metabolome profi for breast cancer diagnosis. InBMC bioinformatics 2010 Apr (Vol. 11, No. 2, p. S4). BioMed Central. 2010;11(2):4.

22. Poschke I, Mao Y, Kiessling R, de Boniface J. Tumor-dependent increase of serum amino acid levels in breast cancer patients has diagnostic potential and correlates with molecular tumor subtypes. Journal of Translational Medicine. 2013 dec;11(1):290-298.

23. Lv W, Yang T. Identification of possible biomarkers for breast cancer from free fatty acid profiles determined by GC-MS and multivariate statistical analysis. Clinical Biochemistry. 2012 Jan 1;45(1-2):127-33.

24. Hadi NI, Jamal Q, Iqbal A, Shaikh F, Somroo S, Musharraf SG. Serum Metabolomic Profiles for Breast Cancer diagnosis, Grading and Staging by Gas Chromatography-Mass Spectrometry. Scientific Reports. 2017 May 11;7(1):1715.

25. Shen J, Yan L, Liu S, Ambrosone CB, Zhao H. Plasma metabolomic profiles in breast cancer patients and healthy controls: by race and tumor receptor subtypes. Translational Oncology. $2013 \mathrm{dec}$ 1;6(6):757-65.

26. Trivedi DK, Hollywood KA, Goodacre R. Metabolomics for the masses: The future of metabolomics in a personalized world. New horizons in translational medicine. 2017 Mar 1;3(6):294-305.

27. van RijswijkM, BeirnaertC, Caron C, Cascante M, Dominguez V, Dunn WB, Ebbels TM, Giacomoni F, Gonzalez-Beltran A, Hankemeier T, Haug K. The future of metabolomics in ELIXIR. F1000Research. 2017;6.
28. Chae EY, Shin HJ, Kim S, Baek HM, Yoon D, Kim S, Shim YE, Kim HH, Cha JH, Choi WJ, Lee JH. The role of high-resolution magic angle spinning $1 \mathrm{H}$ nuclear magnetic resonance spectroscopy for predicting the invasive component in patients with ductal carcinoma in situ diagnosed on preoperative biopsy. PloS one. 2016 Aug 25;11(8):e0161038.

29. Rakha EA, Chan S. Metastatic triple-negative breast cancer. Clinical Oncology. 2011 Nov 1; 23(9):587-600.

30. Silva CL, Passos M, Câmara JS. Solid phase microextraction, mass spectrometry and metabolomic approaches for detection of potential urinary cancer biomarkers-a powerful strategy for breast cancer diagnosis. Talanta. 2012 Jan 30;89:360-8.

31. Bro R, Kamstrup-Nielsen MH, Engelsen $S B_{\text {, }}$ Savorani F, Rasmussen MA, Hansen L, Olsen A, Tjonneland A, Dragsted LO. Forecasting individual breast cancer risk using plasma metabolomics and biocontours. Metabolomics. 2015 Oct 1;11(5):1376-80.

32. Playdon MC, Ziegler RG, Sampson JN, Stolzenberg-Solomon $\mathrm{R}$, Thompson $\mathrm{HJ}$, Irwin $\mathrm{ML}$, Mayne ST, Hoover RN, Moore SC. Nutritional metabolomics and breast cancer risk in a prospective study. The American Journal of Clinical Nutrition. 2017Jun 28;106(2):637-49.

33. Yu L, Jiang C, Huang S, Gong X, Wang S, Shen P. Analysis of urinary metabolites for breast cancer patients receiving chemotherapy by CE-MS coupled with on-line concentration. Clinical Biochemistry. 2013 Aug 1;46(12):1065-73.

34. Menezes GL, van den Bosch MA, Postma EL, El Sharouni MA, Verkooijen HM, van Diest PJ, Pijnappel RM. Invasive ductolobular carcinoma of the breast: spectrum of mammographic, ultrasound and magnetic resonance imaging fi ings correlated with proportion of the lobular component. SpringerPlus. 2013 Dec;2(1):621-33.

35. Nam H, Chung BC, Kim Y, Lee K, Lee D. Combining tissue transcriptomics and urine metabolomics for breast cancer biomarker identification. Bioinformatics. 2009 Sep 25;25(23):3151-7.

36. Bro R, Kamstrup-Nielsen MH, Engelsen SB et al. Forecasting individual breast cancer risk using plasma metabolomics and biocontours. Metabolomics. 2015 Mar 10; 11:1376-1380.

37. Playdon MC, Ziegler RG, Sampson JN, et al. Nutritional metabolomics and breast cancer risk in a prospective study. The American Journal of Clinical Nutrition. 2017 Jun 28; 106(2): 637-649.

38. Menezes GL, van den Bosch MA, Postma EL, et al. Invasive ductolobular carcinoma of the breast: spectrum of mammographic, ultrasound and magnetic resonance imaging finding correlated with proportion of the lobular component. Springerplus 2013 Nov 20; 2:621-633.

Received: 2018-05-01 